\title{
NOx Emission Reduction in Flue Gas of Coal Fired Thermal Power Station and its Control Measures by Secondary Measures
}

\author{
T. P. Meikandaan, M. Hemapriya, V. Vidhya
}

\begin{abstract}
The ever increasing demand for power is mostly met out by electricity produced with the available resources. One such source where generation of power is by making use of the fossil fuel such as coal. Thermal generation using coal accounts for $69 \%$ of the total power produced in India. Flue Gases emitted from coal fired thermal stations consists of CO2,(Carbon-di-oxide),SOx (Oxides of Sulphur), NOx (Oxides of Nitrogen), PM (Particulate matter) along with carbonaceous material, soot and Fly ash. These gaseous pollutants are considered as environmental burden which ultimately results in smog formation, formation of acid rain, eutrophication and global warming which has to be controlled and regulated within the permissible limits as stipulated by MOEF \&CC (Ministry of Environmental Forest and Climate Change). This project describes about the analysis of reduction of NOx Emission in Flue Gas of Coal fired thermal stations and the measures to control the NOx emission within the permissible limits for the new thermal power plants by treating the flue gas emitted from the stack. The secondary measure to reduce the NOx emission is achieved by treating the flue gas with urea or ammonia which bring about $90 \%$ NOx emission reduction. The application of Low Nox Burner with Over Fire Air Technology along with Selective Catalytic Reduction in the new thermal power plant reduce the emission of NOx to a considerable extent and to meet the norms.
\end{abstract}

Key words: Low NOx Burner, Over Fire Air, SCR,SNCR, NSCR.

\section{INTRODUCTION}

The increasing population together with industrial development warrants to meet out the power generation demand. The most probable solution is setting up large thermal power plants to meet the consistently growing electricity demand, since the land requirement is very less, easy to maintain, economical cost of generation and most of all consistent power generation.

The major portion of power generation worldwide is through coal. India's electricity sector is dominated by fossil fuels, and in particular coal, which during 2017-18 produced about three fourths of all electricity. The main advantage of setting up large thermal power plants, is such that it produces

Revised Manuscript Received on December 11, 2019

* Correspondence Author

T.P. Meikandaan *, Department of Civil Engineering, Bharath Institute of Higher Education and Research, Selaiyur, Chennai, Tamilnadu

M.Hemapriya, Department of Civil Engineering, Bharath Institute of Higher Education and Research, Selaiyur, Chennai, Tamilnadu

V.Vidhya, Department of Civil Engineering, Bharath Institute of Higher Education and Research, Selaiyur, Chennai, Tamilnadu

consistent power and unseasonal. India is majorly dependent on coal for its energy needs. We have vast resources of high-grade coal in several states. Coal is the main source of energy in India as it fulfils almost 67 per cent of the total commercial energy consumed in the country [1-7].

\section{A. Classification of coal}

Coal, the world's most plentiful fossil fuel often known as 'Black Gold'. is originated from organic matter wood. Due to decomposition of forests and due to heat from below and pressure coal takes centuries to complete. Based on the carbon content present in the coal, they are classified as follows:

\begin{tabular}{|l|l|l|}
\hline Type of coal & $\begin{array}{l}\text { Carbon } \\
\text { Content }\end{array}$ & $\begin{array}{l}\text { Calorific } \\
\text { Value }\end{array}$ \\
\hline Anthracite & $\mathbf{8 0 - 9 5 \%}$ & Very high \\
\hline Bituminous & $60-80 \%$ & High \\
\hline Lignite & $40-55 \%$ & Medium \\
\hline Peat & $>40 \%$ & Low \\
\hline
\end{tabular}

The coal utilized for age in India is for the most part sub-bituminous coal, which has low Sulfur, low calorific esteem and high debris content and is broadly utilized for creating steam control and modern reason. All things considered, the Indian power plants utilizing India's coal supply devour about $0.7 \mathrm{~kg}$ of coal to create a $\mathrm{kWh}$, moderately lower calorific worth, combined with high debris content and wasteful ignition advancements exasperates outflow of ozone depleting substances and different toxins from India's coal and lignite based warm power plants [8-12].

\section{B. Composition of coal}

The coal is analysed both qualitatively and quantitatively by Proximate and Ultimate Analysis. [13-18].

Proximate analysis of coal examines the chemical composition of a coal sample. Moisture, Volatile compounds, Ash content, Fixed carbon. Proximate analysis used to ascertain "Rank" of coals as the above parameters will indicate the Heating value of the coal.

Moisture in the fuel determines the amount of water present in fuel. 10 
Typical compositions and analysis of (mass percentages) of coal include :

Proximate Analysis

Inorganic mineral matter (ash) - > 50\%. Moisture levels - 2 to $20 \%$,

Volatile matter and fixed carbon.

Ultimate Analysis

$\begin{array}{lll}\text { Carbon } & - & 65-95 \%, \\ \text { Hydrogen } & - & 2-7 \% \\ \text { Oxygen } & - & \text { up to } 25 \% \text { oxygen } \\ \text { Sulphur } & - & 10 \% \text { and } \\ \text { Nitrogen } & - & 1-2 \% \% .\end{array}$

\section{FORMATION OF NOX}

Nitrogen and oxygen are available in a lot of sum in the ignition space and during burning high temperature is delivered to encourage the oxidation of nitrogen and consequently NOx is created.

Overwhelming impact in the development of NOx are temperature and oxygen fixation, the higher the temperature and higher the home time at high temperature in the chamber, the more noteworthy is the measure of NOX produce.

The development of NO is impacted by the grouping of oxygen (which relies upon the overabundance air) in the framework, the fire temperature, the ignition conditions and nitrogen content in coal. Burning of coal changes over the nitrogen bound in coal to frame items, for example, nitric oxide (NO), nitrogen dioxide (NO2) and nitrous oxide (N2O). These items are on the whole called oxides of nitrogen (NOx) - a significant contamination. By and large, 90-95\% of NOx discharged from coal control plants is as NO. In all burning there are three open doors for NOx arrangement. They are:

1. Fuel NOx - Fuel NOx is formed by the reaction of nitrogen in the fuel with oxygen in the combustion air. Fuel NOx contributes about 70- 80 per cent of the total NOx formed when coal combustion occurs in boiler at typical temperature ranges.

$$
\mathrm{O}+\mathrm{N} 2=\mathrm{NO}+\mathrm{N}
$$

2. Thermal NOx - Warm NOx is shaped when nitrogen and oxygen in the burning air consolidate with each other at the high temperatures in a fire. Warm NOx makes up most of NOx framed during the burning of gases and light oils and record for around 5-25 percent of the NOx shaped during coal ignition.

3. Prompt NOx - Brief NOx is shaped from atomic nitrogen noticeable all around consolidating with fuel in fuel-rich conditions which exist, somewhat, in all ignition. Brief NOx represents under 5 percent of the complete NOx emanations [19-22].

\section{IMPACT OF NOX ON ENVIRONMENT}

NOx contributes to Acid Rain leading to damage to vegetation and Aquatic Life.

- NOx is affecting Ozone (O3) balance, is a precursor for photochemical smog contributors (Ozone, PAN, HNO3)

in troposphere which causes damage of the human respiratory system (lungs).

- NOx can contribute to eutrophication and influences ecosystem by nutrient overload.

\section{EFFECTS OF COMBUSTION OF COAL IN THERMAL POWER PLANTS}

Setting up the coal before sustaining into the kettle is a significant advance for good ignition. Further to the abovementioned, size of coal has a significant influence to guarantee productive ignition. Appropriate coal estimating, with explicit significance to the sort of terminating framework, helps towards consuming, decreased debris misfortunes and better ignition proficiency.

The vent gas comprises of different air toxins discharged from warm power plants which depend to a great extent upon the attributes of the fuel copied, temperature of the heater, real air utilized, and any extra gadgets to control the outflows. Some new plants utilize low NOx burners for high temperature (> $1500 \mathrm{~K})$ ignition advances if smokestack tallness is less than 275 meters.

As per the new environmental regulations dated 7.12.2005, the MOEF \& CC has stipulated that the NOx emission has to be within $300 \mathrm{mg} / \mathrm{Cubic} \mathrm{Nm}$ for

the thermal power plants commissioned between 2004 and 2016 and $\quad 100 \mathrm{mg} / \mathrm{Nm} 3$ for the thermal power plants commissioned after 2017.

\section{IMPACT OF NOX ON ENVIRONMENT}

\section{A. INDIAN STANDARD METHOD MEASUREMENT OF NOX FROM STATIONARY SOURCES}

There are two types for Monitoring and measurement of the gaseous pollutants emitted from the power plants namely, Continuous Emission Monitoring System(CEMS) Predictive mission Monitoring System (PEMS)

Out of the above, CEMS-Records emissions continuously over an extended and uninterrupted period of time as cited vide reference (1). The CEMS data provides the most accurate emission. The system employed for monitoring is Non Extractive In-Situ System and stack sampler is used for measurement of NOx. Vide ref (7) the Colorimetrically using phenoldisulphonic acid (PDA) method employed is based on the Indian Standards : IS 11255 (Part 7) : 2005 Methods for measurement of Emission of xides of Nitrogen from Stationary sources [23-25].

\section{B. PRINCIPLE OF COLLECTION OF SAMPLE}

The guideline is to gather a snatch test in a weaken Sulphuric corrosive hydrogen peroxide engrossing arrangement and the nitrogen oxides, aside from nitrous oxides are estimated colorimetrically utilizing the phenoldisulphonic corrosive.

The apparatus employed for collection of a grab of sample is done through a probe and analysed in the lab as shown below 
SAMPLING APPARATUS FOR NOX MEASUREMENT

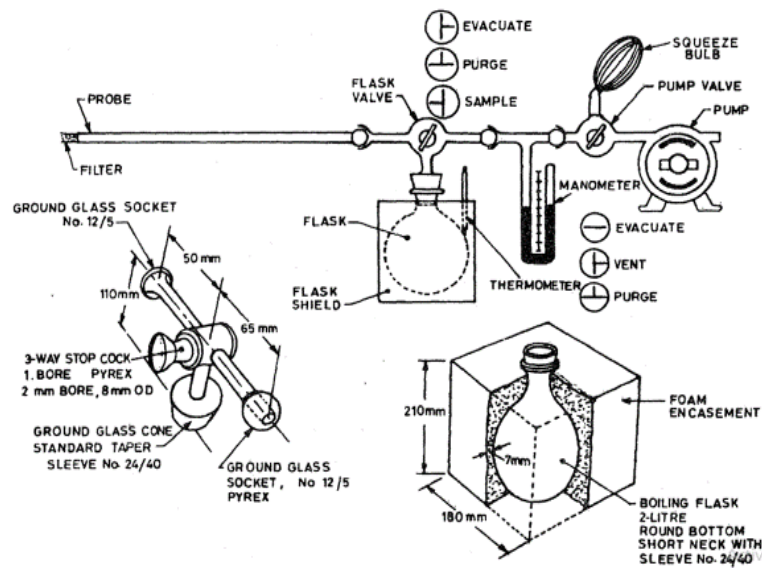

Fig 1. Sampling Train

\section{DATA COLLECTED}

Samples were collected at the stack at two different pass and the NOx emitted in the flue gas is measured. The initial readings taken at the stack are as detailed below:

Table I : Initial readings of Nox emitted at stack

\begin{tabular}{|c|c|c|c|c|c|}
\hline \multirow{2}{*}{ PASS } & \multirow{2}{*}{$\begin{array}{c}\text { Sample } \\
\text { No. }\end{array}$} & $\begin{array}{c}\text { Stack } \\
\text { Temp. } \\
\left({ }^{\circ} \mathbf{C}\right)\end{array}$ & \multirow{2}{*}{$\begin{array}{c}\text { Velocity } \\
(\mathbf{m} / \mathbf{s})\end{array}$} & $\begin{array}{c}\text { Actual Values } \\
(\mathbf{m g} / \mathbf{N m 3})\end{array}$ & $\begin{array}{c}\text { Oxygen } \\
\text { as O2 (\%) }\end{array}$ \\
\hline \multirow{2}{*}{ PASS A } & Sample I & 129 & 11.9 & 724 & 8.92 \\
\cline { 5 - 7 } & Sample II & 130 & 12.5 & 912 & 9.21 \\
\hline \multirow{2}{*}{ PASS B } & $\begin{array}{c}\text { Sample } \\
\text { III }\end{array}$ & 127 & 13.2 & 895 & 10.70 \\
\cline { 5 - 7 } & $\begin{array}{c}\text { Sample } \\
\text { IV }\end{array}$ & 131 & 13.7 & 785 & 10.32 \\
\hline
\end{tabular}

\section{OXYGEN CORRECTIONS}

The results of NO2 has been compared with MoEF\&CC Emission Norms (2015) for Thermal Power Plants. It is observed that value of $\mathrm{NO} 2$ is exceeding the norms, where the stack temperature is in the range of 127 to $131{ }^{\circ} \mathrm{C}$ and the oxygen measured is in the range between 8.92 to $10.70 \%$ as can be seen from the data collected.

The excess air may be considered reason for dilution of flue gas and reducing the stack temperature $<135^{\circ} \mathrm{C}$. This low stack temperature causes condensation in exhaust duct line and stack. This may result into acid corrosion in flue gas path. There may be leakage from Air Pre Heater (APH) tubes, Electrostatic precipitator (ESP) - hopper bottom flange and multiple inspection window and fan inlet flange connection. Hence the exact value of NOx emitted could be obtained only after applying Oxygen Correction.

Oxygen corrections are applied at $6 \%$ Oxygen to the flue gas emissions for Nitrogen Di Oxide (NO2) from the measured $\mathrm{O} 2 \%$ by using CPCB Guidelines on Methodologies for Source Emission Monitoring, LATS/80/2013-2014. An amendment was issued vide GOI, MoEF \& CC Extraordinary Gazette dt. 29.06.2018. for O2 correction. The data of $\mathrm{NO} 2$ at measured $\mathrm{O} 2$ and calculated at $6 \% \mathrm{O} 2$.

Concentration values in $\mathrm{mg} / \mathrm{Nm} 3=$

Actual Concentration in $\mathrm{mg} / \mathrm{Nm} 3 \times$ x $[(21-\mathrm{Os}) /(21-\mathrm{Om})]$

(Corrected Values with 6\% O2)

\section{E. READINGS AFTER OXYGEN CORRECTIONS}

After applying Oxygen correction the values are tabulated as below:

Table II : Calculated Readings after oxygen correction

\begin{tabular}{|l|l|l|l|c|}
\hline \multirow{2}{*}{ PASS } & Sample No. & $\begin{array}{l}\text { Stack } \\
\text { Temp. } \\
\left({ }^{\circ} \mathrm{C}\right)\end{array}$ & $\begin{array}{l}\text { Velocity } \\
(\mathrm{m} / \mathrm{s})\end{array}$ & $\begin{array}{l}\text { Corrected Values } \\
\text { with 6\% O2 }\end{array}$ \\
\cline { 4 - 6 } & & 129 & 11.9 & NO2 (mg/Nm3) \\
\hline \multirow{2}{*}{ PASS A A } & Sample I & 129 & 899 \\
\cline { 2 - 5 } & Sample II & 130 & 12.5 & 1160 \\
\hline \multirow{2}{*}{ PASS B B } & Sample III & 127 & 13.2 & 1303 \\
\cline { 2 - 5 } & Sample IV & 131 & 13.7 & 1103 \\
\hline
\end{tabular}

\section{Analysis of nox emitted}

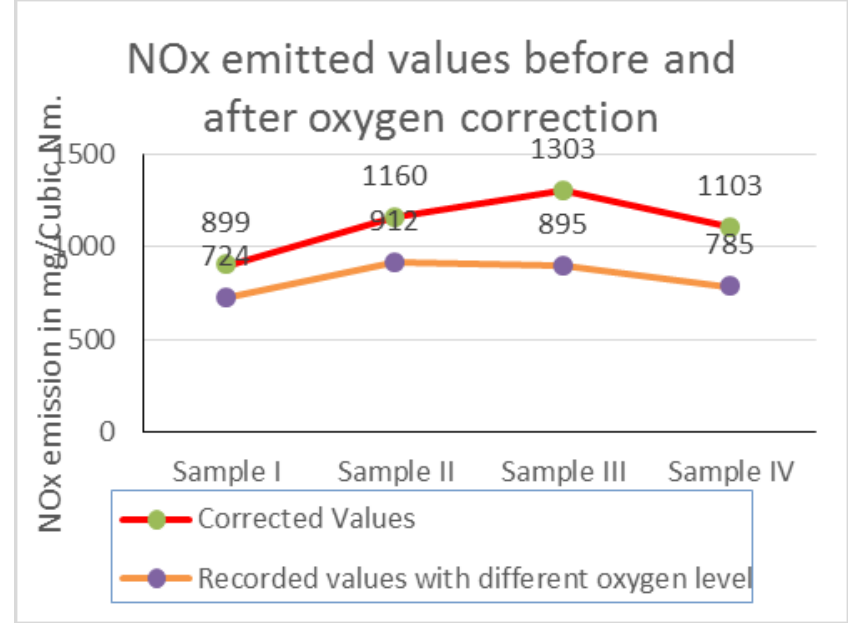

Fig. 2. Analysis of NOx Emitted

\section{TECHNOLOGY TO CONTROL EMISSION OF NOX}

Various control technology are being employed to regulate the emission of NOx emitted in the flue gas. Primary techniques are applied to reduce emissions at source. The innovation of denitrification during ignition ordinarily embraces the low NOX innovation as the universal path for it's well-created innovation and the ease. By and by, the NOX expulsion effectiveness is for the most part beneath $40 \%$. The innovation, which uses the NOx burners as its initial step to diminish the half substance of NOx in the vent, at that point utilizes the denitrification after ignition as the subsequent advance to finish the denitrification, is broadly utilized in nations that are exacting with the NOx emanation. For this it makes use of various techniques such as

- Low NOx Burner (LNB)

- Over Fire Air (OFA)

- Burners Out Of Service (BOOS)

- Flue gas recirculation (FGR)

- Staged Combustion

- Fuel Reburning

Secondary Techniques treat pollutants after they are released into flue gases. 


\section{SELECTION OF OPTIMUM MEASURES}

Various control measures are analysed and the optimum control measure is selected for implementing the same to achieve the NOx emission reduction within the permissible norms.

The plants that have to meet the NOx emission limit of $100 \mathrm{mg} / \mathrm{Nm} 3$ will be required to go for post combustion NOx control. However, even these plants should first consider adopting primary NOx control technologies as they can significantly reduce the operating costs associated with post combustion control technologies.

Managing the catalyst in SCR system is a serious concern that merits stringent storage and disposal regulations and close oversight by the PCBs. Majority of coal in India is of poor quality and thermal power industry has raised concerns about the suitability of SCR for NOx control in Indian context. Independent experts believe that SCR technology will work for Indian coal, however, the erosive ash components such as silica and alumina will have an impact on the SCR and its catalyst causing a faster deactivation of the catalyst [26, 27].

\section{RESULTS}

For the thermal power plants commissioned after 2017 the latest technology for reduction in NOx emission well below $100 \mathrm{mg} / \mathrm{Nm}^{3}$, is to make use of Low Nox Burners along with Over Fire Air Port which reduces NOx during combustion. Further to this NOx reduction upto $95 \%$ is achieved by making use of post combustion treatment ie. By using Selective Catalytic Reduction that reduces the NOx to Nitrogen and Water. Power stations across the country have now begun the process of implementing the secondary control measure by using Selective Catalytic Reduction. This method is considered to be cost effective and reduction is achieved upto the maximum level [28].

\section{A. LOW NOX BURNER (LNB) AND OVERFIRE AIR PORT}

A. Kettle burners are the focal component of successful ignition framework structure which incorporates fuel readiness, air fuel dissemination, heater plan and ignition control. A burner supplies required measure of fuel and air and makes a state of quick blending and produce fire. The blending of air and fuel legitimately influences the fire security, shape and discharge.

\section{B. LOW NOX BURNER}

The technique involved in the Low Nox Burner is that it comprises of two stages namely Split up of flame and Air staging

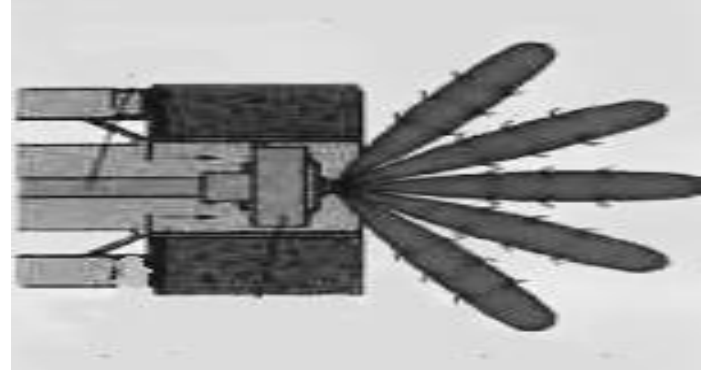

Fig 3 Split up of flame in LNB
Air stagging (AS). The combustion air staging is realized by a nozzle set, by injecting the secondary air directly into each portion of flame.

The LNB can reduce the emission of NOx upto $60 \%$ maximum. This can be one of the least expensive pollution prevention technologies.

\section{OVER FIRE AIR (OFA)}

Divert typically diverts $20-30 \%$ of the combustion air from the burners to the upper furnace to stage the combustion process beyond what can be achieved with low-NOx burners i.e a portion of the combustion air away from the primary combustion zone minimizing the formation of fuel NOx.

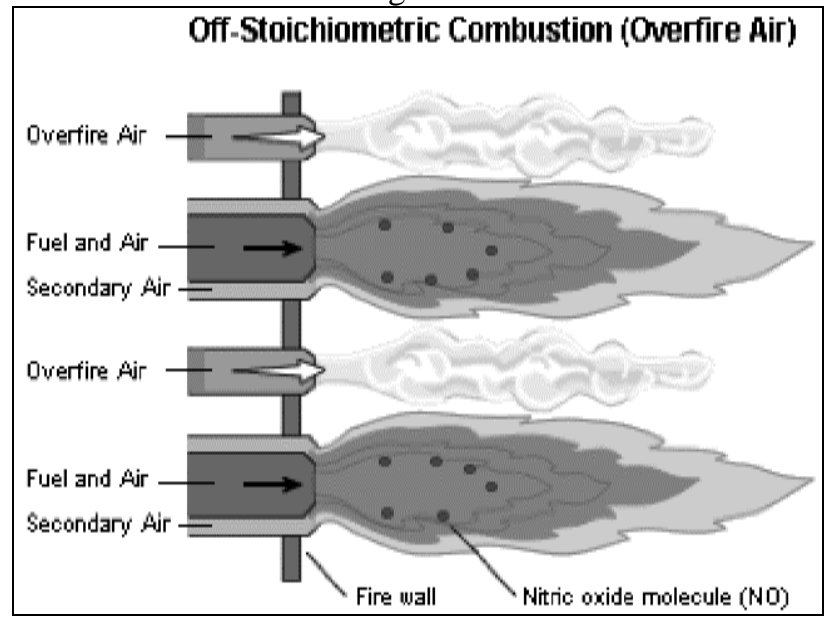

Fig. 4 Over Fire Air

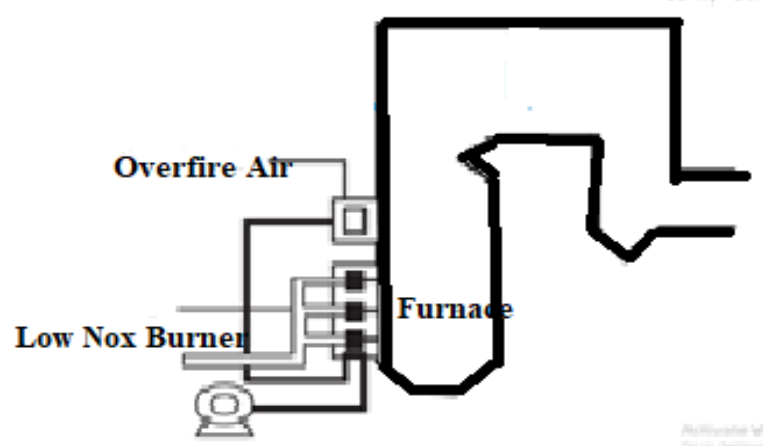

Fig.5. Line Diagram of position of low NOx Burner and OFA

\section{SECONDARY CONTROL MEASURE}

The most common secondary measures are -

- SCR ( Selective catalytic reduction) :-

- SNCR( Selective non catalytic reduction) :-

- NSCR - Non-selective Catalytic Reduction

\section{A. SELECTIVE CATALYTIC REDUCTION (SCR)}

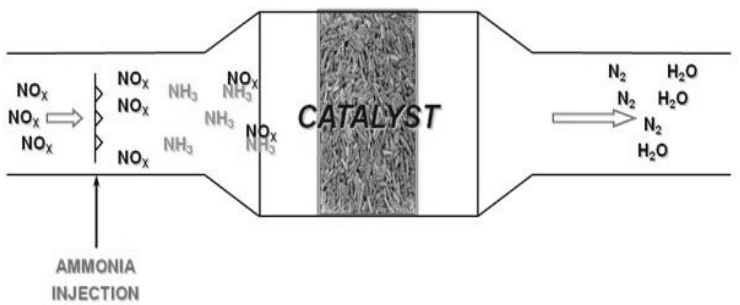

Fig 5. NOx Abatement 


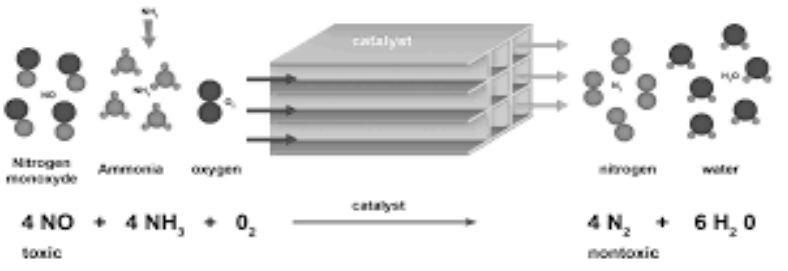

Fig 6. SCR REDUCTION PROCESS

\section{E. TECHNOLOGY BEHIND SCR}

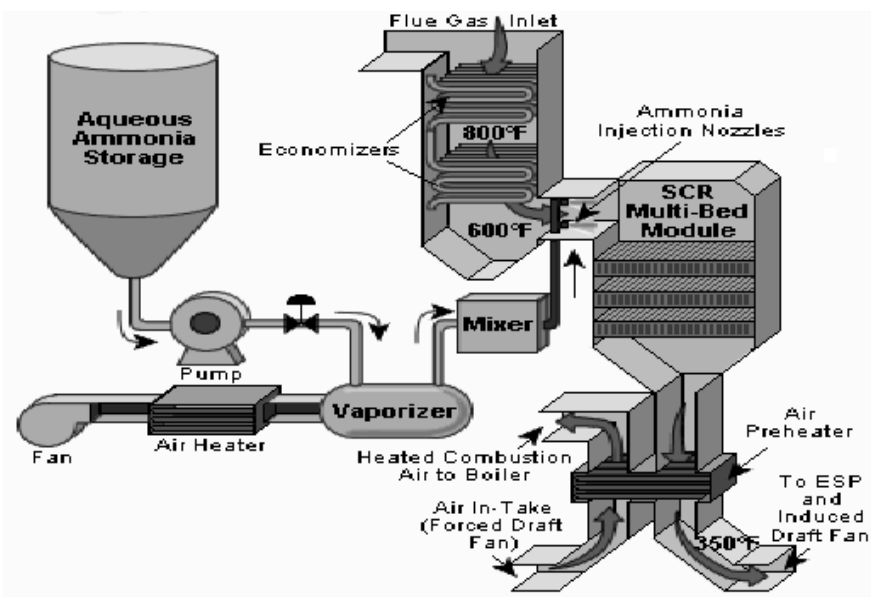

Fig 7. NOx Removal in SCR

The catalyst system can be of honeycomb, metal plate or corrugated design.

Ammonia is used as part of neutralizing NO, according to the following chemistry:

$4 \mathrm{NO}+4 \mathrm{NH}_{3}+\mathrm{O}_{2} \rightarrow 4 \mathrm{~N}_{2}+6 \mathrm{H}_{2} \mathrm{O}$

$6 \mathrm{NO}+4 \mathrm{NH}_{3} \rightarrow 5 \mathrm{~N}_{2}+6 \mathrm{H}_{2} \mathrm{O}$

The proper design of the ammonia injection system is critical for complete mixing in the flue gas steam.

\section{F. TYPICAL DIAGRAM OF POWER PLANT USING SCR FOR NOX REMOVAL}

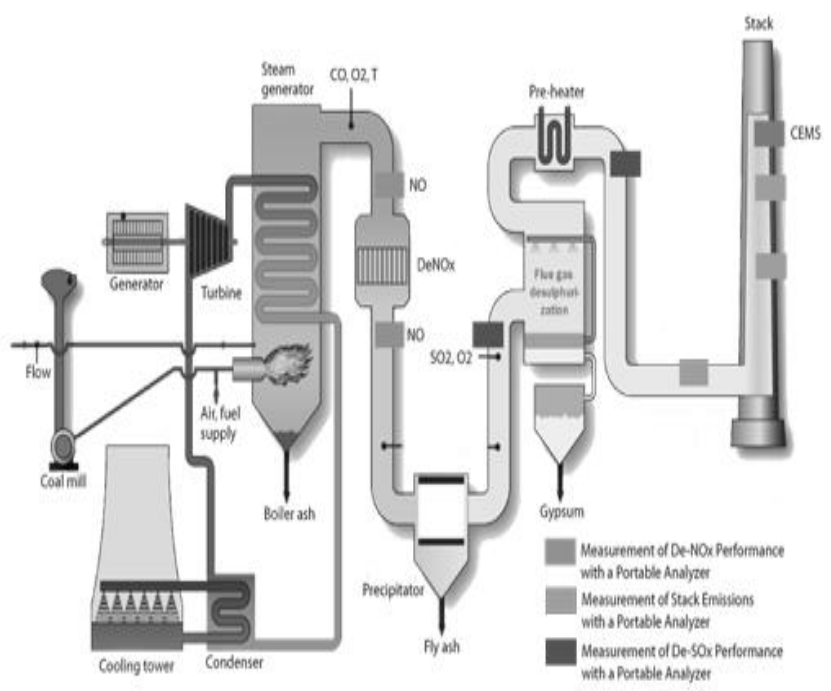

Fig 8. Diagram of Thermal Power plant fitted with SCR

\section{G. ADVANTAGES and DISADVANTAGES OF SCR OVER SNCR}

The advantages of SCR are

- Very high $\mathrm{NO}_{x}$ removal (as much as $97 \%$ ) with less ammonia slip $(<10 \mathrm{ppm})$.

- Operates at a comparatively lower temperature between $150-600 \operatorname{deg}[29,30]$.

Disadvantages include

- High Capital and Investment cost

- Safety concerns with storage and handling of ammonia,

- Higher flue gas pressure drop, especially if the catalyst bed gradually gets plugged.

- Major Plot area required

- Disposal of Spent Catalyst

- Very short life of the catalyst which means maintenance within short period

From the various study it is seen that even though the initial cost and operating cost are very high for thermal plant fitted with Selective Catalytic Reduction, the NOx reduction efficiency is proved to be around $95 \%$ at a lower temperature which is as shown below:

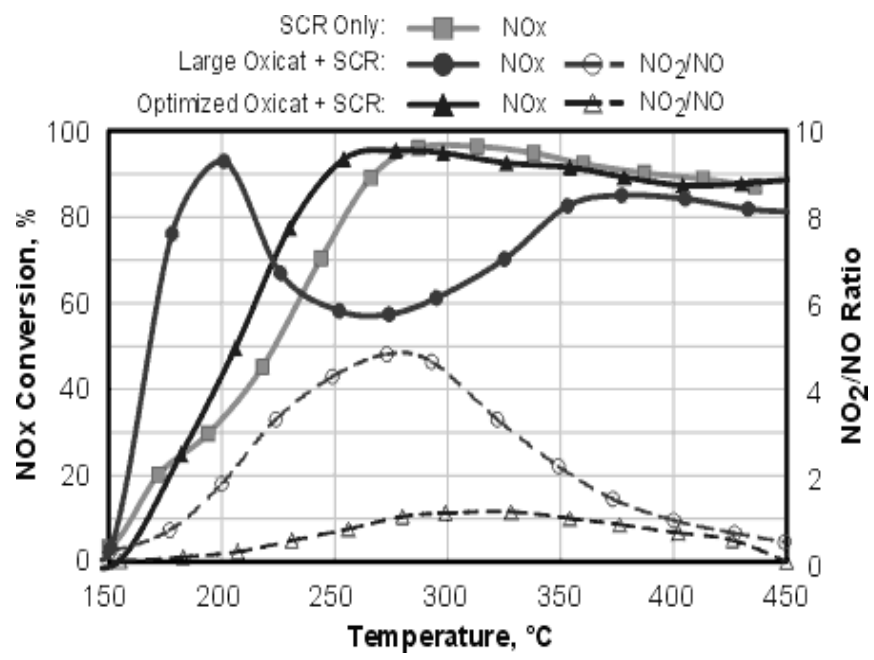

Apart from the above, the particulate matter is also removed to some extent.

\section{H. LIMITATIONS OF SCR}

- SCR technology has a high initial cost.

- Catalysts used in SCR have a finite life in flue gas and some ammonia "slips through" without being reacted.

- SCR systems are sensitive to contamination and plugging during normal, and abnormal, operations.

- Certain pollutants in flue gas can render the system ineffective at NOx reduction, or cause oxidation of ammonia present (forming more NOx).

- SCR systems have operational difficulty with binding of the catalyst by fly ash. Because of these issues, SCR catalysts have a limited operational lifetime of 16 to 40 thousand hours in coal-fired power plants, depending on the flue gas composition. 
- Though SCR systems have been documented as more effective in NOx removal, SNCR systems are often favored due to their lower cost since they do not use a catalyst.

\section{CONCLUSION}

The results showed reduction of various exhaust gas not only NOX. If using catalytic converter the most harmful gases should be minimized. Pollution should be controlled.

Almost all the new thermal power plants commissioned after 2017 are to be fitted with Low NOx Burner along with Over Fire Air Port to reduce combustion in the source and to achieve the maximum NOx Reduction emission the effective secondary measure such as Selective Catalytic Reduction has to be installed since the reduction in NOx emission has been fixed as $100 \mathrm{mg} / \mathrm{Cubic} \mathrm{Nm}$, wherein the reduction efficiency works out to $95 \%$.

\section{REFERENCES}

1.Andreea Voina, Brandusa Pantelimon, Georgeta Aleca, Incd Ecoind International Symposium-Simi 2011 "The Environment And The Industry" Methods for measurement, monitoring and control of NOX emissions

2.Besire Cena*, Mehush Aliu, Tahir Musliu during the year 2010 in the Journal of Environmental Application and Science published a paper on “" Measurements of Emission of Gases SO2, NOx, CO and $\mathrm{CO} 2$ from the Burning Process in the Furnaces of Power Plant "Kosova B" vide Vol. 5 (2): 172-174 (2010)

3. Chandra H, Paliwal S, and Tripathi A, “ Mitigation Of Emission In Thermal Power Plant Using Conventional And Non-Conventional Fuel", International Journal of Engineering Science Invention Vol 2 issue $4 \mathrm{Apr}$ 2013 pp 01-06.

4. Dongmei Li, Yang Guo, Yuan Li, Pengguo Ding, Qiang Wang, Zhenqian Cao, " Air Pollutant Emissions From Coal-Fired Power Plants", Haepc electric power research institute, zhengzhou, china. Published in the Open journal of Air Pollution (2012,1,37-41)

5.Dr Malgorzata Wiatros-Motyka 'NOx control for high-ash coal-fired power plants in India . Clean Energy, Volume 3, Issue 1, 27 February 2019, Pages 24-33,

6.Eng. Florentina CĂLUGĂRU, Conf. PhD. eng. “ Installation of Low Nox Burners at $100 \mathrm{MW}$ units of Bucharest south thermal power plant" in his paper published in Termotehnica 2/2012

7.Guidelines of Continuous Emission Monitoring System issued by Central Polution Control Board during the year July 2017.

8.James E. Staudt, Ph.D. "Control Technologies To Reduce Conventional And Hazardous Air Pollutants From Coal-Fired Power Plants", Andover technology partners, Prepared for NorthEast states for coordinated air use management (2011)

9.John H. Margeson, William J. Mitchell , Jack C. Suggs \& M. Rodney, “ Integrated Sampling And Analysis Methods For Determining NOx Emissions At Electric Utility Plants", Journal of the Air Pollution Control Association, 32:12,1210-1215 published on Mar 2012 Midgett

10.Kenichi Ochi, Kenji Kiyama,Hidehisa Yoshizako, Dr. Eng.,Hirofumi Okazaki, Masayuki Taniguchi, Dr. Eng. " Latest Low-NOx Combustion Technology for Pulverized-coal-fired Boilers “, Published in Hitachi Review Vol 58 (2009), No.5.

11.Kishore B Porate, Krishna L.Thakre, Gana Shyam L. Bodhe, "Minimization Of GHG In Coal Based Thermal Power Plant", Published in the Journal of Electrical Engineering.

12.Levaggi. D.A ,Zerrudo.R, Karels.G, Oyung.W \& Feldstein.M (2012) “An Integrated Manual Impinger Method for The Simultaneous Determination of NOx and Sox in Source Effluents, Journal of the Air Pollution Control Association, 26:8, 783-786 Published during March 2012.

13.Li.J and Li.W.W, "Control Technology Research on Low-NOx Combustion System in Large-Scale Coal-Fired Power Plants", Advanced Materials Research, Vols. 953-954, pp. 730-733, 2014

14.Ministry of Environment and Forest -Guidelines for the measurement of Ambient Air Pollutant- Guidelines for Manual Sampling and AnalysesIssued by Central Pollution Control Board.

15. Marc Karell and Amit Chattopadhyay (2000) -“NOx Emission Reduction Strategies in the Journal Pollution Online

16. Moo Been Chang, How Ming Lee, Feeling Wu \& Chi Ren Lai (2004) "Simultaneous Removal of Nitrogen Oxide/Nitrogen Dioxide/Sulfur
Dioxide from Gas Streams by Combined Plasma Scrubbing Technology, Journal of the Air \& Waste Management Association, 54:8, 941-949,

17.Moti L. Mittal, Chhemendra Sharma and Richa Singh "Estimates of Emissions from Coal Fired Thermal Power Plants in India "Council of Scientific and Industrial research during the year 2010

18. Nihalani S.A, Mishra Y, Juremalani J, "Emission Control Technologies For Thermal Power Plants IOP conference series : Material Science and Engineering (2018), Gujarat, India

19.Ravi K. Srivastava, Robert E. Hall , Sikander Khan , Kevin Culligan \& Bruce W. Lani 2012 in the Journal of the Air \& Waste Management Association published “ Nitrogen Oxides Emission Control Options for Coal-Fired Electric Utility Boilers”, vide Vol , 55:9, 1367-1388

20..Satyashree Godka, Rohit Kumar, Navneet Singh, Himani Khandelwa, "Estimation Of GHG Emission From Indian Coal Based Thermal Power Plant", Published in IOSR journal of Engineering Apr 2012, Vol.2(4) pp: 591-597

21.Shahzadbaig K, Yousuf M, "Coal Fired Power Plants: Emission Problem And Controlling Techniques", Published in the Journal of Earth Science and Climatic Change (2017), Ryerson university, Toronto, Canada,

22.Sujatha K, Bhavani P.G, Godavari T, Ponmagal R.S, and Su-Qun Cao. "Smart Sensor For NOx and SO2 Emissions In Power Station Boilers", Published in the Indian Journal of Science and Technology, Vol 8 (27) Oct 2015

23. Sunil P.Agarwal " in his paper on "Practical approach to SOx and NOx Measurement

24. Yuan Ji Pei, Ge Li, Xiang Qi Wang, Yun Wu Zhang, Guang Yao Feng, Yong Wang, Wei Wei, Yili Hong, Shaojun Fu, Hui Gao, Yu Xiong Li, Hong Jun Zhou, Yang Cao Tian, Lei Shang, Xiao Li Dong, Sai Dong, Liu Si Sheng," A Low cost and high efficient facility for removal of SO2 and NOx in the flue gas from Coal Fire Power Plant "in his proceedings on the Particle Accelerator change held at Chicago during the year 2001.

25. .Zhu Liang Wang, Lei Wang, De Shi Yin, Ting Fa Zhang " The Technique of NOx Emission Control in 1000 MW Thermal Power Unit Boilers", Advanced Materials Research, Vols. 383-390, pp. 6097-6102, 2012

26.Mosrati, J.; Atia, H.; Eckelt, R.; Lund, H.; Agostini, G.; Bentrup, U.; Rockstroh, N.; Keller, S.; Armbruster, U.; Mhamdi, M. Nb-Modified $\mathrm{Ce} / \mathrm{Ti}$ Oxide Catalyst for the Selective Catalytic Reduction of NO with NH3 at Low Temperature. Catalysts 2018, 8, 175.

27.Yiming Yang,Jian Li \& Hong He "Research and Proposal on Selective Catalytic Reduction reactor Optimisation for Industrial Boiler" Published in 'Journal of the Air and Waste Management Association”'Vol. 68, 2018 Issue -7

28.Mengfan $\mathrm{Fu}$, Caiting Li, Pei Lu, Long Qu - A review on SCR of NOx by supported catalysts at 100-300 deg. C- Catalysts Mechanism, Kinetics Published in Catalysis Science \& Technology Jan. 2014.

29.Junhua Li, Huazhen Chang- Lei Ma, Ralph T.Yang- Low Temperature Catalytic Reduction of NOx with NH3 over metal oxide \& Zeolite Catalyst, Oct 2011.

30.M.Varathvijayan,Prasanth. B.Chandran - Experimental investigation and emission reduction test of Bio Diesel by using Selective Catalytic Reduction for Diesel Engine Published in Journal International Journal of Advanced Engineering Research and Studies, Oct - Dec. 2014/ Pg. $39-42$.

\section{AUTHORS PROFILE}

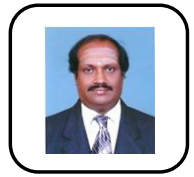

T.P. Meikandaan, Associate Professor, Department of Civil Engineering, Bharath Institute of Higher Education and Research, Selaiyur, Chennai, Tamilnadu

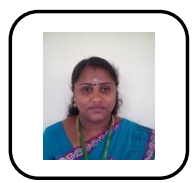

M.Hemapriya, Assistant Professor, Department of Civil Engineering, Bharath Institute of Higher Education and Research, Selaiyur, Chennai, Tamilnadu

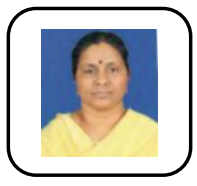

V.Vidhya, Department of Civil Engineering, Bharath Institute of Higher Education and Research, Selaiyur, Chennai, Tamilnadu 